\section{Public participation: a need of forest planning}

\author{
Xabier Bruña-García, Manuel Francisco Marey-Pérez
}

Stakeholder participation in decisions related to forest planning is essential to get long-lasting and viable solutions. Nowadays, public participation is necessary to reach consensus in natural resource management and in citizen governance of land. It is a key element in a forest planning on a strategic level. However, only the first steps are being taken to include public participation in forest planning within the forestry sector. This paper proposes a review of public participation processes in forest planning as a reference for the development of new methodologies in areas with no previous experience in participative processes. The assessment of the existing scientific literature and its use in different models and countries show a high diversity of responses to the challenge of including social aspects and integrating them with methodological proposals.

Keywords: Collaborative Decision Making, Forest Planning, Models of Public Participation, Participative Planning, Public Participation

\section{Introduction}

"Forest resource planning is a very complex problem mainly due to the multiplicity of wide-ranging criteria involved in the underlying decision-making process" (DíazBalteiro \& Romero 2008). One of the criteria to be taken into account is the social as pect. Public participation is one of the questions that is raising more interest within social aspects. As other articles on the same topic (Buchy \& Hoverman 2000, Sheppard \& Meitner 2005), this paper reviews the state of the art in research on public participation within the forest sector and its possible application in forest resource planning, focusing on regional planning.

The aim of this work is to show to forest planners the importance and the progress made in public participation in forest planning in the last forty years. It also aims to show how these social techniques have been modified, increased and adapted to the different social and territorial realities through time.

We started with a review of research papers related to public participation in forestry. The search for information focused on three

topics: (1) from a conceptual perspective, the concepts of society, democracy and public participation, their historical evolution and their relation with forest planning; (2) key elements for the development and success of a public participation process in forestry; (3) most widely-used models, methods and tools. The paper ends with a discussion section and conclusions that reflect the lessons learned from the literature.

\section{Brief review of the conceptual framework}

There have been important social changes worldwide in the last forty years. On the one hand, in western Europe, north America, Japan and Australia, post-industrial societies have lost their connection with forest land (Tourain 1969). They have incorporated a bigger network of connections among its citizens by means of new information technologies, which implies a higher level of information and interest of participation in social and environmental issues on a global, national, regional and local scale. On the other hand, there have been fewer changes in pre-industrial societies in Asia, Latin Ame-

\footnotetext{
Escola Politécnica Superior, Dept. Agroforestry Engineering, University of Santiago de Compostela, E-27002 Lugo (Spain)
}

@ Xabier Bruña-García (ringojbg@yahoo.es)

Received: Feb 21, 2013 - Accepted: Oct 03, 2013

Citation: Bruña-García X, Marey-Pérez MF, 2014. Public participation: a need of forest planning. iForest 7: 216-226 [online 2014-02-27] URL: http://www.sisef.it/iforest/ contents/?id=ifor0979-007

Communicated by: Luca Salvati rica and Africa (Alexander \& Thompson 2008). However, there is an increasing interest in participating in decision-making regarding the management of closer and necessary forest resources.

Claims for participation are often made in terms of democracy. From a democratic perspective, the equitable inclusion of different interests is a key issue in public participation (Primmer \& Kyllönen 2006).

There are different approaches to the definition of public participation. According to the COST Action FP0804 (2010) FORSYS, public participation means that citizens are involved in the environmental or natural resource decision-making that affects them. In more general terms, public participation is a process by which people make decisions about the institutions, the programmes and the environments that affect them (Glück 1999, Shannon 1999).

In an initial proposal, participation is considered an awareness process by which people begin to understand their political role and the need for a legitimate conciliation of opinions and for a contribution to the planning process (Sewell \& O'Riordan 1976). This makes participation a requirement to build consensus and a basic principle which brings about transparency and an exchange of information (Glück 1999, Shannon 1999, Hiedanpää 2005). Thus, participation brings about a sense of self-realisation and property (Dovie 2003). In a modern sense, public participation is a voluntary process where people, individually or by means of organized groups, can exchange information, express opinions, articulate interests and have the potential to influence the end result (ILO 2000, Aasetre 2006, Atmis et al. 2007).

From the point of view of citizens, participation in the forest sector must become a method used by the whole forest organization instead of making it a pre-requisite for forest management (Atmis et al. 2007). The process of forest policy implies a set of private interests, public agencies, legal framework, groups of lawyers and judicial organizations and non-profit organizations which represent the expansion actions of the public (Janse \& Konijnendijk 2007). These nonprofit organizations gained influence in forest policy (Weber \& Christophersen 2002), so resource management agencies worldwide are increasingly using processes of public participation to involve those citizens affected by planning decisions (Hjortsø 2004).

From the point of view of the administration, participation is the effort of the forest planning and management team to provide people with a wide range of opportunities to influence planning and forest management. Participation also enables them to systematically analyze, assess and subsequently incor- 
porate the resulting public contributions into forest plans as often as possible (Domínguez et al. 2005, Marey-Pérez \& Rodríguez-Vicente 2009). "The quality of the process is seen as key to high quality appraisal outcomes" (Garmendia \& Stagl 2010).

From the point of view of landscape, participation is the capacity of the local population to decide and develop their own rules and structures (Gómez-Vázquez et al. 2009). These will guarantee the use, the maintenance and the development of the landscapes that satisfy their needs and those of their offspring (Penker 2009).

Participatory approaches focus on people. They must be implemented with caution. It is necessary to take into account key concepts such as "empowerment, respect, localization of resources, enjoyment and inclusiveness of people" (Pretty et al. 1995).

\section{Antecedents and evolution of public participation in forest planning}

Society claimed a more important role in the decisions related to public land and forests in the 1960s due to the beginning of the environmental movement (Scardina et al 2007). Since the 1970s, there has been a reassessment of the value of local knowledge leading to petitions of participation in projects in which experts and local knowledge were complementary. It is necessary that research into environmental decision considers the different scenarios of construction of knowledge, as this will provide insights into people's response to matters like forest loss or species preference (Martin 2003). The report by the Brundtland Commission in the 1980s showed that equity would be favored by political systems in which public participation ensures decision-making. Thus, public participation was directly joined with sustainable development (World Commission on Environment and Development 1987). In the same way, and according to Primmer \& Kyllönen (2006), participation is essential for sustainable development as a source of pertinent environmental information for decision-making. Therefore, it is now central to the concept of sustainable development Currently, public participation in decisionmaking in the forest sector is considered an important part in sustainable forest management (Kangas et al. 2005, 2010, Cantiani 2012).

The preamble of the Agenda 21, approved in the United Nations Conference on Environment and Development (Río de Janeiro 1992), states that a high participation of the public opinion in decision-making is a basic requirement for sustainable development. Moreover, the need for new means of participation became obvious in the more specific context of environment and development "Participatory approaches are argued to be an essential part in applying the precautionary" (Primmer \& Kyllönen 2006).

The reinforcement of the public role in planning has its roots in philosophical and pragmatic considerations. From a philosophical point of view, democratic societies believe that citizens are entitled to being provided with information and asked about their opinion regarding issues that affect them (Germain et al. 2001). The ideal would be to have a democratic government which is representative and designated to channel and assimilate information between the government and those governed (Sewell \& O'Riordan 1976, Germain et al. 2001).

Some economists defend environmental methods for participative decisions in which the public are considered as citizens instead of consumers (Swedeen 2006). It is widely accepted nowadays that participative methods are the most efficient ones to get sustainable resource management. Local communities are asking for more voice and influence in the management of their resources (Leskinen 2004, Mendoza \& Prabhu 2006). This requires a more direct and active participation of a higher number of stakeholders and the incorporation into planning of the interests, perceptions and visions that society has about forest resources.

Although public participation is not a new concept, its presence in forest planning is relatively new, being an uncommon practice at local level in non-industrial private forest land (NIPF - Leskinen 2004). People are gradually more interested in having more control over the decision-making process and in influencing forest practice. There is also a growing interest in a change in forestry practices (Buchy \& Hoverman 2000). This is the reason why those professionals in forestry need to communicate their ideas and actions, not only to other professionals, but also to a higher number of nonprofessionals (Tyrväinen et al. 2006). Sugimura \& Howard (2008) recommend the participation of stakeholders in the final phases of forest zoning.

According to Ojha et al. (2009), the search for efficient strategies to protect forests and improve the lives of those who depend on them lead to several participative approaches to forest government worldwide in the last decades. In this sense, public participation is key in the forest sector and constitutes a new framework for any type of decision-making in forestry (Kouplevatskaya-Yunusova \& Buttoud 2006). Public participation can also be a tool to improve sustainable forest management (ILO 2000, Atmis et al. 2007). This makes it an important tool in many countries to promote sustainable forest management on a strategic level, especially in public or state forests (Hiltunen et al. 2008, Kangas et al. 2010, Cantiani 2012).

\section{Foundations for the success of public participation in the forest sector}

\section{Principles and aims}

Participation can be considered as an end or as a means to an end, as ethics of performance or as a management tool (Buchy \& Hoverman 2000).

On the one hand, according to Buchy \& Hoverman (2000), good participative planning presents four basic principles: (i) commitment and clarity; (ii) time assigned to the process; (iii) representativeness of the people involved; (iv) transfer of competences and knowledge. On the other hand, many studies show that learning, relationship building, exchange of knowledge and representation of interests are the measures of the success of public participation (Shindler \& Neburka 1997, Richard \& Burns 1998, Tuler \& Webler 1999, McCool \& Guthrie 2001, Leskinen 2004).

It is necessary to guarantee equity, representativeness and transparency in public participation processes (Kangas et al. 2005). Participative planning may be used to avoid conflict, share information among participants and promote good relations with the organization that promotes the planning (Hellström 2001, Kangas \& Store 2003, Janse \& Konijnendijk 2007, Hiltunen et al. 2009). The development of a National Forest Program (NFP) is a challenge. It may contribute to the processes of democratization in different ways: by reinforcing the transparency of political decisions, by making communication and decision processes more pluralistic, by stimulating mutual knowledge and by increasing awareness of collective responsibility for forest issues (Elsasser 2002, Kangas et al. 2010). Public participation is increasingly recognized as an instrument for environmental management through the building of consensus, conflict management and collaboration for problem-solving and negotiation in decision-making (Hjortsø 2004).

Public engagement in forest management decisions will bring about an increase in the value of landscapes and the recognition of sustainable forests. As landscapes start to be perceived differently, this new perceptions will help "address ecological sustainability and will embrace the new ecological aesthetic idea" (Panagopoulos 2009). To this regard, goals for public participation have been developed founded on sustainable development and on development policies. They include the generation of new pertinent information, the inclusion of different interest and the contribution to reach a public consensus (Primmer \& Kyllönen 2006).

\section{Types of public participation in forest planning \\ Four types of public participation can be}


found in forest-planning processes:

- None: there is no chance of participating in the decision-making process.

- Public: open access and input into the decision process, such as in a public forum (Kangas et al. 2006, Meitner et al. 2005).

- Restricted Public: invited access, however no specific knowledge is required to inform and enter the decision process, such as community group participation (Seely et al. 2004, Lexer et al. 2005, Mendoza \& Prabhu 2005).

- Stakeholder: Experts or stakeholders provide information and participate in the decision process (Acuña et al. 1997, Twery \& Hornbeck 2001, Vacik \& Lexer 2001 , Mendoza \& Prabhu 2003)

There are several degrees of participation from passive participation, in which stakeholders are informed about the decisions made by others, to interactive participation which requires joint decisions and shared responsibilities (Germain et al. 2001, Elsasser 2002, Higgs et al. 2008). Therefore, participation may have different forms which range from public meetings and audiences, questionnaires (focused on groups) to deliberative processes with the final aim of enabling participants to have a higher degree of involvement in decision processes (Higgs et al. 2008). Martins \& Borges (2007) interpret the collaborative planning "as a special case of participatory planning when all participants involved share decision-making power and are directly affected by management options".

The literature offers several typologies of public participation. It often shows a scale which stems from a unidirectional information flow until it completes the power of decision of the citizens in self-organization (Arnstein 1969, Pretty 1994, Elcome \& Baines 1999, Germain et al. 2001, Dovie 2003, Sugimura \& Howard 2008, Stenseke 2009). Taking this into account, we propose the five levels below:

1.Information: unidirectional information flow without public participation to obtain feedback and without negotiation.

2. Consultation: the role of citizens is to review and comment the planning proposals by means of audiences and consultations, while the authority retains the power of decision.

3. Decision: citizens and authority become partners. Citizens begin to have influence in the decisions. They can negotiate and be involved in compensations with the authorities.

4.Performance: citizens have a dominant control over the decision-making of the authorities and they are also responsible for the decisions.

5. Self-organization: citizens have full control, so it is the highest expression of citizen power. They take initiatives which are independent from the authorities.

Public participation implies the egalitarian participation of the different stakeholders, "including industry, labor unions or other non-governmental organizations" (Primmer \& Kyllönen 2006). Moreover, their contemporary use implies more direct ways of public participation than just voting in the elections, the membership to a political party or the affiliation to an interest group involved in political decision-making. Limiting participation to owners leaves too many groups out of the decision space in many decisions concerning natural resources.

\section{Phases of public participation}

The work by Martins \& Borges (2007) suggests a simplification of the collaborative planning process in three steps:

- The identification of the problem involves the gathering and analysis of information to understand and define the management of territorial problems.

- The modeling problem consists on the construction of models to represent the relationships between the management alternatives and the results and the policy management scenarios.

- Problem solving implies the design of a forest management plan.

According to Collier \& Scott (2009) the participation of stakeholders, consultation, participation and inclusion are some of the most commonly-used descriptors of the collaboration, planning and management process. New methods of reconciliation of social and ecological differences are becoming increasingly important in restoration ecology, collaborative planning and management. These new methods are adequate tools to reach agreements, mend trust relations and encourage mutual learning.

\section{Advantages and disadvantages of public participation}

Public participation has many advantages that have been exposed in different articles. They can be grouped in the following categories: improvement of communication, generation of knowledge, rapprochement between the administration and government and citizens, involvement of all agents, integration of society in management, improvement of sustainable development, prevention and solution of conflicts, legitimization of decision-making, easier execution of the plan and step towards forest governance.

\section{Improvement of communication}

Public participation is more efficient when it is based on mutual confidence. It improves the communication and cooperation among all those involved in the process. This will contribute to sustainable forestry, increasing public awareness. It will also contribute to the increase in forest benefits, to the fair dis- tribution of costs and profits and to the improvement of the social acceptance of sustainable forestry (Düzgün 2003). The use of social movements can cause a decrease of prejudices against the forest sector (Côté \& Bouthillier 2002, Sugimura \& Howard 2008).

\section{Generation of knowledge}

Hansmann et al. (2006) state that participative processes with more widely-spread marketing campaigns may be a source of information for the Swiss population about the forest sector. Information can contribute to a certain improvement in the quality of decisions (Côté \& Bouthillier 2002, Sugimura \& Howard 2008). Additionally, there is an educational dimension as an advantage, which may bring long-term benefits (Buchy \& Hoverman 2000) and, therefore, public participation can incorporate new data and generate knowledge (Brody \& Cash 2004, Brody et al. 2006, Saarikoski et al. 2010).

\section{Rapprochement between the administra- tion and government and citizens}

The study by Berninger et al. (2009) states that the consequences of different management options should be discussed and effectively communicated to improve the attitudes of the locals towards forestry. This will improve the understanding of the complexity of the task of managing a big forest area with socio-economic and environmental criteria and increasing their confidence on forest professionals.

\section{Involvement of all agents}

Selman (2004) considers the collaboration of stakeholders as a key element in landscape management and planning. Undoubtedly, it offers the opportunity to participate in the forest planning process, which will make more people consider the importance of forests (Sugimura \& Howard 2008). Among the reasons why industry is interested in public participation, we find good public relations, a good relationship with stakeholders and a decrease of criticism in the media (Brody \& Cash 2004, Brody et al. 2006).

\section{Integration of society in management}

Public participation improves the effective management of resources (Brody \& Cash 2004, Brody et al. 2006, Buchy \& Hoverman 2000, Cantiani 2012). The study by Brody et al. (2006) identifies some of the most important factors that encourage forestry and the wood industry to take part in the participative management of ecosystems. It concludes that the participation of industry can bring about an improvement in the results of the management of the ecosystem and a contribution to the achievement of the goals in the management of natural resources by companies. 
Currently, public participation must help create synergies between stakeholders and managers, achieving a better integration between environment, economy and society (Mose \& Weixlbauner 2007, Panagopoulos 2009) and facilitating future management by consensus (Booth \& Halseth 2011).

\section{Improvement of sustainable development}

Public participation is important in successful strategies of conservation (Alexander 2000). Participative methods are the most effective ones to achieve sustainable resource management (Leskinen 2004, Mendoza \& Prabhu 2006). Moreover, Brody et al. (2006) studied the thirty-eight biggest forest companies in the US and found that the use of participative management to create collaborations and associations with stakeholders results into more effective resource management.

\section{Prevention and solution of conflicts}

According to Dovie (2003) "Local participation should not be seen as means of reducing cost, engaging cheap labor and/or the opportunity to tap free knowledge. However, it should be seen as a foundation for conflict resolution, benefit sharing and partnership development. It is also meant to enhance the socio-economic lives of the people, bringing hope and in the long term, providing them with opportunities to be accountable for their environment". An example of public participation as an effective way of managing forest conflicts is the Mountain Forest Tending Group in Switzerland. This is where the representatives of the Federal Forest Services discuss the way to combine the management of natural stands, the protection against risks (especially landslides) and the preservation of biodiversity (Niemelä et al. 2005). Therefore, public participation can be used to reduce the conflicts between stakeholders (Côté \& Bouthillier 2002, Sugimura \& Howard 2008, Cantiani 2012) and it is an attractive alternative to litigation and to regulation control (Brody \& Cash 2004, Brody et al. 2006).

\section{Legitimization of decision-making}

A rational technical-scientific model that does not include the preoccupation of the public makes it difficult to reach decisions that are acceptable for citizens (Shindler et al. 2002, Sugimura \& Howard 2008). Therefore, public participation in the decisionmaking process improves the possibility to reach a consensus by enabling the stakeholders to take into account different perspectives. This makes the decision-making process more transparent by giving more responsibility to those who make the decision and adds more weight to the final decision (Higgs et al. 2008). The legitimacy of the final decision can be better when the different stakeholders participate in decision-making (Webler et al. 1995).

\section{Easier execution of the plan}

Even if participative planning requires a higher initial investment, the involvement of the residents in the planning phase can lead to lower costs later because it avoids complaints in the execution phase (Sipilä \& Tyrväinen 2005). Therefore, the involvement of citizens will cause lesser stakeholder opposition to the execution of forest plans (Sugimura \& Howard 2008)

\section{Step towards forest governance}

This new variable should be incorporated and accepted in the planning of forest resources since it is the only way to achieve forest governance. There will be a strengthening of democracy and an expansion of citizens rights (Higgs et al. 2008). Participative planning can also improve the quality of life of the residents with positive experiences of participation and empowerment and improve their lives in a more tangible way once the plan is carried out (Sipilä \& Tyrväinen 2005).

Nowadays public participation presents some problems with its implementation, which will be solved by applied research. In this line, Conrad et al. (2011) illustrate the inadequacy of present legal requirements for ensuring effective participation, and a related need for institutionalizing review mechanisms in Mediterranean countries. In Canada, Stewart \& Sinclair (2007) detected some problems in the processes of public participation in environmental assessment.

Some of the problems detected by different studies are described below. First, public participation is costly and lengthy (Stenseke 2009). Moreover, the politicians and scientists responsible for management have criticized participative approaches in relation to their highly-qualitative orientation and their apparent lack of rigor, structure and a systematic process to analyze and interpret the data from the stakeholders (Mendoza \& Prabhu 2005).

The planning of natural resources is complex in itself and it often implies a set of participants with different perspectives about the means and ends applied (Hjortsø 2004). Several participation processes related to environmental issues in the USA fail to establish a constructive dialogue among society and stakeholders, which hinders the solution of conflicts (Swedeen 2006). This may be due to the possibility of being influenced by the participants, their self-organization, their possible implication in hierarchies, the coordination and the rules of decision within discussion groups (Elsasser 2002).

Suárez de Vivero et al. (2008) make reference to the paradox of participation: the higher the number of actors, the smaller the role that each one has and the lesser importance of the traditional sector. The increasing number of participants and the complex relations between them due to their different interests make it necessary to redefine the rules of participation. Therefore, some clear rules of negotiation and participation are necessary in order to overcome obstacles and achieve effective participation (Elsasser 2002).

The negligent application of public participation could cause conflicts with local societies with long term effects on relationships and on the local capacity to collaborate (Stenseke 2009), as it could be used as a channel of opposition. Participation can also raise too many expectations if the essence of planning is not understood or if the principles of decision-making are not clear. In practical terms, participative planning sometimes leads to compromises where individual expectations are not fully satisfied (Tyrväinen et al. 2006, Sipilä \& Tyrväinen 2005). Local participation in the management of cultural landscape is very efficient when focused on specific areas. However, it cannot substitute politics and administrative organization when it comes to global strategies for areas on a big scale (Selman 2004, Stenseke 2009).

\section{Models, methods and tools}

According to Sheppard \& Meitner (2005), "while there is an increasing demand for active public involvement in forestry decisionmaking", there are still few successful models to reach this goal in new sustainable forest management (Marey-Pérez et al. 2006). The methods described as "hard" are consistent with the traditional and rational scientific management approach based on mathematical models. "Soft" methods and knowledge-based system approaches are introduced as having potential, particularly in participatory modeling as they are applied to forest and natural resource management planning (Mendoza \& Martins 2006). The participation models can be used as independent tools or they can be integrated in planning to make it stronger and more flexible (Mendoza \& Prabhu 2006). There is no method that is universally best or even applicable for all situations (Kangas \& Kangas 2005). Based on the nature of the alternatives, Hajkowicz et al. (2000a) classify Multi-Criteria Decision-Making (MCDM) methods under two major categories: continuous and discrete. That is why their election requires the consideration of the needs in each particular case. Not all techniques can be applied on every level of participation. Therefore, the planner's goals should not be ambiguous, especially when interacting with the public (Buchy \& Hoverman 2000). In this regard, as stated in Cost Action FP0804 (2010), there are different types of methods and tools in each phase of public 
Tab. 1 - Models, methods and tools in each phase of public participation.

\begin{tabular}{|c|c|c|c|c|c|}
\hline Phase & Methods & Tools & Examples & Models & Sources \\
\hline \multirow[t]{6}{*}{ Organization } & Citizens' juries & - & - & Public forums & McDaniels \& Roessler 1998 \\
\hline & Public meetings & - & - & - & - \\
\hline & Working groups & IT-based tools & Mesta & - & Hiltunen et al. 2009 \\
\hline & Informal methods & - & - & - & - \\
\hline & Formal methods & - & - & - & - \\
\hline & PPGIS & - & - & - & $\begin{array}{l}\text { Anderson et al. 2009, Brown \& } \\
\text { Reed } 2009\end{array}$ \\
\hline \multirow[t]{6}{*}{ Intelligence } & Survey & IT-based tools & $\begin{array}{l}\text { Mesta, Monsu GIS } \\
\text { Internet }\end{array}$ & Grounded theory & Domínguez Torres 2008 \\
\hline & Cognitive mapping & - & - & AHP & Ananda \& Herath 2008 \\
\hline & Interviews & - & - & SWOT and AHP & Silvennionen et al. 2001 \\
\hline & Brainstorming & - & - & FCM & Mendoza \& Prabhu 2006 \\
\hline & Workshop & - & - & $\begin{array}{l}\text { Social Evaluation method } \\
\text { (SE) }\end{array}$ & Sugimura \& Howard 2008 \\
\hline & Delphi method & - & - & Q Method & Swedeen 2006 \\
\hline \multirow[t]{5}{*}{ Design } & Brainstorming & Forest simulators & Mesta & Fuzzy approaches & Mendoza \& Martins 2006 \\
\hline & Working group & Optimization tools & SODA & Soft approach systems & Purnomo et al. 2004, Hjortsø 2004 \\
\hline & $\begin{array}{l}\text { Problem structure } \\
\text { methods }\end{array}$ & $\begin{array}{l}\text { Heuristic pro- } \\
\text { grammes }\end{array}$ & $\begin{array}{l}\text { SADflOR, DTRAN, } \\
\text { MONSU, MONTE }\end{array}$ & Integrated approach & $\begin{array}{l}\text { Belton \& Stewart 2002, Kangas et } \\
\text { al. } 2006\end{array}$ \\
\hline & Delphi method & - & - & Integrated model & Mendoza \& Prabhu 2005 \\
\hline & Workshop & - & - & Compared scenarios & Côté \& Bouthillier 2002 \\
\hline \multirow[t]{5}{*}{ Choice } & Voting method & Optimiation tools & - & Social choice theory & Kangas et al. 2006 \\
\hline & Negotiation method & - & - & - & Laukkanen et al. 2005 \\
\hline & Negotiation method & - & - & - & Martin et al. 1996 \\
\hline & Several & MCDA Tool & - & MCDA & Mendoza \& Martins 2006 \\
\hline & Several & - & - & MCDM & Díaz-Balteiro \& Romero 2008 \\
\hline Monitoring & - & - & - & $\begin{array}{l}\text { Hyerarchical Valuation } \\
\text { Scheme (HVS) }\end{array}$ & Dovie 2003 \\
\hline
\end{tabular}

participation, as can be seen in Tab. 1. The revision of collaborative methods and tools that can be used in the elaboration of the management plans of Non-Industrial Private Forests (NIPF) reveals new research needs, the development of hybrid methods and technological platforms for the integration of tools and methods (Martins \& Borges 2007). The methods used should be comprehensible for all those involved in the process. The results and their analysis should not be difficult to evaluate and explain (Kangas \& Kangas 2005).

According to Sheppard \& Meitner (2005), information can be conveyed easily and fast by public processes that introduce prospective schemes with justified solutions.

In the same way, Higgs et al. (2008) highlight the potential of the approaches that include IT (Information Technologies) in public participation, in particular of those that that show the possibilities of the use of Geographic Information Systems (GIS) to include the needs and preferences in the decisionmaking process. Using distributed networks is supposed to allow for a broader application of public participation. An example of this is the use of decision support systems with the tool Mesta (http://www.mesta.met la.fi) in the participative process NRP in the region of Laponia in Finland. An advantage of Mesta was the inclusion of preferences with the realistic production possibilities of the planning regions (Hiltunen et al. 2009).

We propose a review of some of the most widely-used processes of public participation below.

\section{SCT/GDM (Social Choice \\ Theory/Group Decision Making) models without MCDM skills}

\section{Social Choice Theory}

Social Choice Theory as a systematic subject emerged during the French Revolution. Marquis de Condorcet, a French mathematician, started the discipline of social choice in terms of simple majority voting and related procedures, and discovered the paradox of cyclic voting, commonly known as the Condorcet paradox (Arrow et al. 2002).

According to Kangas el al. (2006) "the basic objective of social choice is to combine individual preferences into a collective choice. The social choice situation can be described with four components or parts: (i) voters or players; (ii) choice alternatives; (iii) the information of voters' preferences over the alternatives; (iv) an aggregation device (voting model, procedure or voting method)".

Kant \& Lee (2004) state the four stages in the implementation of Social Choice Theory in the context of sustainable forest management: "(i) identification of all possible forest values; (ii) revelation of the preferences of the stakeholders by different sectors and so- cial strata; (iii) aggregation within the preference group; and (iv) aggregation among the preference groups". Voting is a well-known way of exerting influence and expressing opinions: "The voting approach can be applied in multiple-criteria decision support by voting on criteria" (Kangas \& Kangas 2005).

The methods based on social choice theory have been applied in group decision-making for natural resource management, such as in Martin et al. (1996), Laukkanen et al. (2005), Hiltunen et al. (2009), Vainikainen et al. (2008). In fact, Martin et al. (1996) published one of the first studies about the application of this technique in the USA in the management of forest land rented for oil and gas exploitation. It consisted of two systems of voting regulations (Condorcet and Borda), seven stakeholders and seven alternatives.

Social Choice Theory has been recently applied in Laponia to the decision-making group in the revelation of preferences of the participants in participative forest planning (Vainikainen et al. 2008) or in the participative planning in forest strategy in stateowned forests in Finland with five methods of voting (Hiltunen et al. 2008). Most of the voting techniques are also transparent and the results are easy to apply by decisionmakers and easy to interpret by participants. Contrary to this and according to Vainikainen et al. (2008), in practice, voting is belie- 
ved to be fair as each voter is supposed to have the same influence on the end result However, voters do not have the same power, as it can be seen in the results. This is referred to as strategic behavior and it has not been studied deep enough in public participation. Therefore, the use of several voting methods is recommended.

\section{SCT/GDM (Social Choice \\ Theory/Group Decision Making) models using MCDM skills: discrete} methods

Discrete MCDM methods can be defined as decision support techniques that have a finite number of alternatives, a set of objectives and criteria by which the alternatives are to be judged and a method of ranking alternatives, based on how well they satisfy the objectives and the criteria (Hajkowicz et al. 2000b, Ananda \& Herath 2009).

\section{AHP}

Group preferences can be analyzed using Analytic Hierarchy Process (AHP) or utility functions, as shown in Kangas (1994), Martin et al. (1996) and Ananda \& Herath (2003). AHP is a mathematical method for the analysis of complex decisions with multiple attributes (Saaty 1977, 1980). MauCrimmins et al. (2005) show in their study in the Colorado National Forest (Arizona, USA) that AHP can successfully be applied to the experimental problem of the location of wild natural areas, offering thus possibilities for its effective application as a tool of public participation. In the same way, the work by Ananda \& Herath (2008) concludes that "the AHP and other conventional public consultation procedures are effective ways to improve participatory decision-making in complex decision situations, such as regiona forest planning". Kurttila et al. (2000) describe a method that fused SWOT and AHP in a case of forest certification in Finland Silvennionen et al. (2001) applied an AHP approach provoking preference weights in a case of landscape of forest management. Schmoldt \& Peterson (2000) used a technique based on AHP as a component of fire research planning for forest fires, the Fire-Disturbance Workshop of the USDA Forest Service.

\section{Integrated approach}

A method to integrate the opinion of the residents in relation with forest management is the planning with a participative focus (Tyrväinen et al. 2006). The integrated approach proposed by Belton \& Stewart (2002) presents a mixture between the qualitative approaches of the social aspects and the structural approaches of the more statistical aspects. The work by Tyrväinen et al. (2006) analyzes two possible methods to improve the planning of public participation and its design in Europe, based mainly on acquired experiences in Nordic countries. The methods are related to the use of: (i) methods of visualization by computer; and (ii) model forests and landscape labs. Their combination can cause a considerable improvement in forest planning and design. Alternatively, Mendoza \& Prabhu (2005) describe the application of the integrated model in the management of communal forests in Mafungautsi (Zimbabwe). It proposes an approach to simulate different scenarios combining MCA and participative modeling that uses cognitive mapping, first, and system dynamics, later. By means of a study of the drawbacks of traditional models, they call for new trends of thought concerning Multi-Criteria Decision Analysis (MCDA) when implemented in forest and natural resource management planning.

\section{SCT/GDM (Social Choice}

Theory/Group Decision Making) models using MCDM skills: continuous methods

Continuous methods aim to identify an optimal quantity, which can vary infinitely in a decision problem. Techniques such as linear programming, goal programming and aspiration-based models are considered continuous (Ananda \& Herath 2009).

\section{MCDA and hybrid methods}

These hybrid methods provide the synergistic accumulation of insights from different methods. Traditional participative approaches were criticized for their lack of rigor, so at the end of the $20^{\text {th }}$ century alternatives were presented to correct this deficiency (Mendoza \& Prabhu 2005). The work by Mendoza \& Martins (2006) reviews the limitations of traditional MCDA approaches to incorporate public participation, analyzing soft systems and the alternative paradigms and aiming for a modeling that is transparent, participative and accessible for decision-makers. Concerning this, it has been shown that hybrid methods like Multi-Criteria Decision Support (MCDS) and participative approaches by means of information networks enhance the effectiveness of the process. Moreover, regardless of the planning task or the MCDS method, education and learning improve (Kangas \& Kangas 2005).

It has also been concluded that the planning process will be more efficient using interactive methods. This requires a clearer modeling process (Mendoza \& Martins 2006). Díaz-Balteiro \& Romero (2008) consider that the application of techniques of Group Decision-Making methods (GDM) in the forest sector has a large potential for research. Leskinen \& Kangas (2005) analyzed the use of MCDM methods on a theoretical level when the participating criteria are inter- dependent and proposed the use of statistical models to avoid the uncritical acceptance of the assumption of independence criteria.

Mendoza \& Prabhu (2002) exemplify the integration of the MCDM methods with a soft qualitative model of dynamic system. Recently, Mendoza \& Prabhu (2006) described the dynamics of three general types of soft systems linked to participation models: (1) cognitive mapping; (2) dynamic qualitative system; and (3) Fuzzy Cognitive Mapping (FCM). The last one has more advantages in its application due to its transparency and simplicity.

Tikkanen et al. (2006) analyzed the real objectives of a sample of forest owners following a cognitive mapping approach. Finally, Martins \& Borges (2007) examined different GDM approaches with an MCDM orientation and its potential use in the management of forest problems in Portugal.

\section{Other models}

The Social Evaluation approach (SE) proposed by Sugimura \& Howard (2008) reduces the number of comparisons by pairs of AHP. It simplifies the answering process and lowers survey costs. The Q method is a research approach defended by the advocates of discursive democracy to assess the attitudes about a specific topic from their own perspective. It was used in the north-eastern Pacific area of the US to support public participation (Swedeen 2006). It also included the feelings of the participants towards the process in the making of the Regional Forest Programme in Finland (Kangas et al. 2010).

Multi-Attribute Utility Theory (MAUT) is an approach which can simplify and structure the forest management problem and facilitate explicit incorporation of multiple values and risk preferences of stakeholders in decision-making (Ananda \& Herath 2005).

The work by Côté \& Bouthillier (2002) shows that the use of compared scenarios is an interesting tool to evaluate the opinion of participants about the repercussion of the initiatives of public participation in order to identify the weaknesses of the processes and for the increase in the knowledge of the participants about the possibilities of such exercise.

Dovie (2003) thinks that the Hierarchic Valuation Scheme (HVS) is more suitable for the evaluation of local resource use than other participatory schemes (among them Participatory Rural Appraisal - PRA), as it is more accurate and reliable. HVS may be used as complementary to other techniques. Purnomo et al. (2004) applied a system of soft approaches to the management of a communal property forest with a surface of 30000 ha in Indonesia, selecting six indicators related with the management plan and several defined strategies, in fifteen scenarios assessed by a group of stakeholders. 
Díaz-Balteiro et al. (2009) adapted and applied a method for aggregating individual preferences expressed through pairwise comparison matrices to elicit social weights in the context of a forest management problem to two public forests in Spain.

\section{Internet-based methods and tools}

"Teledemocracy" uses distance communication technologies to add possibilities to citizen participation in decision-making. It solves the problems of geographical isolation, reduces distances and gathers a great number of opinions very fast. It offers opportunities of participation to citizens that cannot attend face-to-face events (Kangas \& Store 2003).

Public Participation Geographic Information Systems (PPGIS) methods increase the rates of participation (Pocewicz et al. 2010), strengthening confidence and increasing cooperation in forest management (Brown \& Reed 2009). They are an important tool to attract people (Brown \& Weber 2011). In the forest sector, the Canadian Forest Service developed the first PPGIS to gather data about the first location of the values of forest landscape through a study area of 2.4 million ha in Alberta (Beverly et al. 2008) and the Nova Forest Alliance in Nova Scotia (Anderson et al. 2009). Other internet-based studies for national forest management have been recently developed in the USA (Brown $\&$ Reed 2009, Clement \& Cheng 2010).

The latest trends in information technologies show that citizens are willing to share information with "web 2.0" tools and crowd sourcing platforms to describe events with social impact (Díaz et al. 2012, Faehnle \& Tyrväinen 2013).

Brown \& Reed (2009) in their assessment of the advantages and disadvantages of internet conclude that results depend on the subpopulation sampled and that their use must be complemented with traditional methods. Cantiani (2012) states that the use of internet must be carefully considered, since, depending on local conditions and the questions under discussion, could lead to the overestimation of the opinions of organized groups.

\section{Discussion and conclusions}

According to Buchy \& Hoverman (2000), it is not possible to categorically answer the question of whether public participation is successful or not. The answer is closely related to the aim of participation. However, we believe that it is possible to determine indicators that can measure the success of public participation, its contributions and that respond to the intensity and scope formulated in the initial conditions of the process. Our work presents the following trends of thought concerning the importance and advances obtained in public participation in forest planning in the past decades:

1. From a theoretical and philosophical per-

16

14

8

6

2

0 .99.

Fig. 1 - Number of articles published in the literature about public participation, grouped by year of publication.

spective, there is no doubt that public participation is a need for democratic societies nowadays (Arnstein 1969, Buchy \& Hoverman 2000, Sheppard \& Meitner 2005, Aasetre 2006, Primmer \& Kyllönen 2006). It is an important tool to reach consensus (Webler et al. 1995, Shindler et al. 2002, Higgs et al. 2008, Sugimura \& Howard 2008), manage conflicts (Dovie 2003, Côté \& Bouthillier 2002, Niemelä et al. 2005, Sugimura \& Howard 2008, Cantiani 2012) and improve forest management (Alexander 2000, Brody et al. 2006, Leskinen 2004, Mendoza \& Prabhu 2006). However, this theoretical clarity is not translated into its application to the territory. On the one hand, public participation is seve-

30

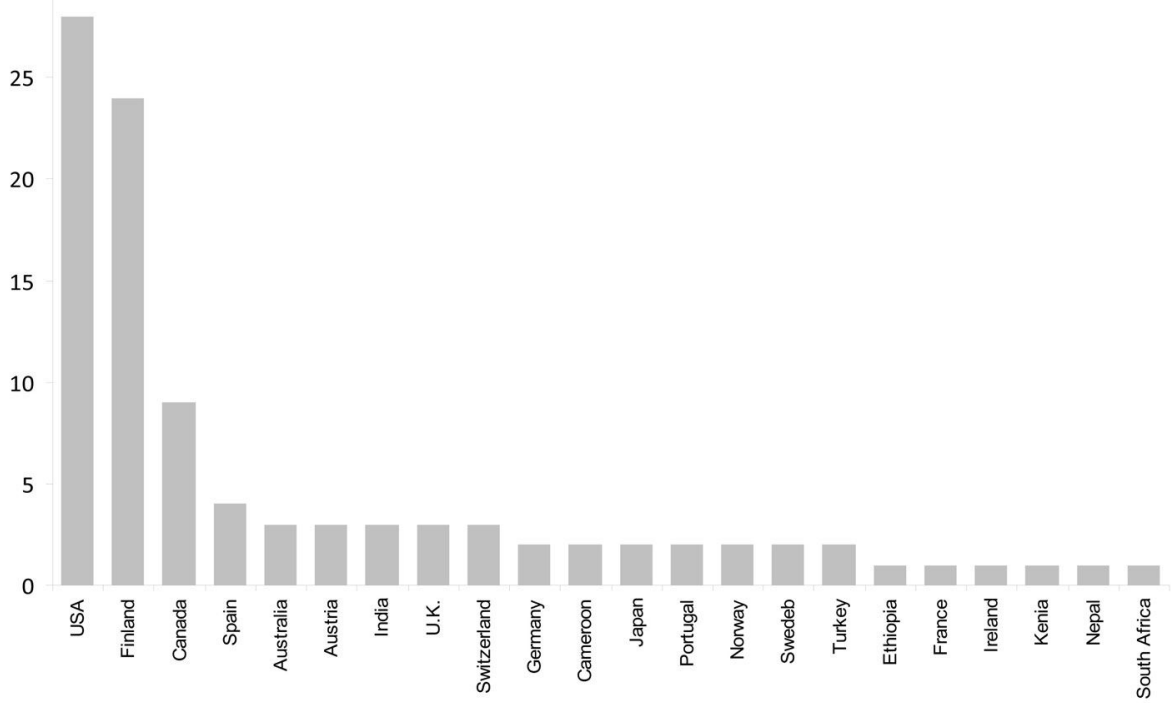

Fig. 2 - Number of articles published in the literature about public participation, grouped by country. rely conditioned in its development by the interests of power groups that see it as a threat for their interests. On the other hand, there is a lack of training which prevents the public interested from facing the participative processes with guarantees.

2. From a historical perspective, considering the extensive bibliography consulted and more than 40 years of scientific development, public participation has not been included as a necessary element for the development of forest planning. However, there has been a growing interest in public participation and its application, as seen in Fig. 1, which shows the highest concentration of work in the last decade regarding public participation. This fact confirms 
that public participation represents one of the future fields of development and innovation in forest planning.

3. From a methodological perspective, despite the advantages of public participation (Webler et al. 1995, Alexander 2000, Buchy \& Hoverman 2000, Côté \& Bouthillier 2002, Shindler et al. 2002, Dovie 2003, Düzgün 2003, Leskinen 2004, Niemelä et al. 2005, Brody et al. 2006, Mendoza \& Prabhu 2006, Higgs et al. 2008, Sugimura \& Howard 2008), it is necessary to make a bigger effort to specify some aspects of its application in the territory and methodology. In this sense, it is necessary to continue to advance in the development of flexible public participation methodologies to be applied in different contexts and by different organizations. In particular, some issues need to be dealt with in a process of public participation in forest planning: diffusion and communication (Janse 2008); representativeness (Beierle \& Cayford 2002, Primmer \& Kyllönen 2006, Higgs et al. 2008); cost and time (Stenseke 2009); methodological rigor (Mendoza \& Prabhu 2005); intensity (Beierle \& Cayford 2002) and optimum number of participants (Suárez de Vivero et al. 2008).

4. From a territorial perspective, the application of public participation in the processes of forest planning does not have enough tradition or experience (Atmis et al. 2007) Its application in the different regions and countries is linked to areas that present more fully developed democratic processes and to countries with more resources and forest tradition (Fig. 2). Therefore, the main criticism towards public participation in forestry is that it should be linked to the basic principles that define sustainable forest management. It is also worth noting, within a territorial perspective, that there are public participation experiences on a local level even if the majority of the processes have been on a regional and/or national level (Sipilä \& Tyrväinen 2005). In this sense, it is necessary to identify the key elements in the processes of public participation on a regional or national level that make them viable. The success of forest plans depends on the representativeness and involvement of the different stakeholders.

5. From a social perspective, taking into account the need to integrate social and technical aspects, the most advanced methods of public participation apply a mix of soft and hard methods (Sheppard \& Meitner 2005, Mendoza \& Prabhu 2005, Kangas \& Kangas 2005, Mendoza \& Martins 2006). However, these methods are still too rigid to obtain clear information about the different preferences and needs of stakeholders, which are essential for the success of public participation processes (Domínguez \& Shannon 2009).

6. From a future perspective, new information technologies can make the decisionmaking more transparent, fluent and equal (Kangas \& Kangas 2005, Higgs et al. 2008, Hiltunen et al. 2009, Cantiani 2012). The identification of significant functional groups is necessary for impact assessment because groups supporting particular functions in a particular network of actors and practices have much influence. They condition the impacts considered (Hiedanpää 2005). However, it is necessary to apply and develop more "intense" processes of public participation. By "intense" we mean a higher involvement of participants in final decision-making. In the coming years, citizen contributions will have more and more relevance in the planning process in the forestry sector.

Public participation in forest planning has been developed and applied differently in time and space. Current experiences are an interesting starting point, but it is necessary to develop contrasted and flexible technologies to be included in the whole process of making forest plans. Methodologies used so far have originated as an answer to the problems and interests of some social groups seeking to influence the process. No methodology was previously designed to be validated in different areas. Therefore, it is necessary to establish the general guidelines for public participation processes with flexible methodologies, so that they can be adapted to different territories. The final result will contribute to the advance in two of the challenges of the $21^{\text {st }}$ century: sustainability and governance.

\section{Acknowledgments}

We would like to thank the Ministerio de Ciencia e Innovación of the Spanish Government for their financial aid through the Proyecto Sectorial Estratégico - Restauración Forestal, subproyecto Implica-Explica (PSS- 310000-2009-22) and COST Action FP0804: FORSYS.

\section{References}

Aasetre J (2006). Perceptions of communication in Norwegian forest management. Forest Policy and Economics 8: 81-92. - doi: 10.1016/j.forpol. 2004.06.001

Acuña S, Juristo N, Recio B (1997). Knowledge-based system for generating administrative grant alternatives applying the IDEAL methodology. Computers and Electronics in Agriculture 18: 1-28. - doi: 10.1016/S0168-1699(97)00015$\mathrm{X}$

Alexander SE (2000). Resident attitudes towards conservation and black howler monkeys in Belize: the Community Baboon Sanctuary. Environmental Conservation 27 (4): 341-350. - doi: 10.10 17/S0376892900000394
Alexander JC, Thompson K (2008). A contemporary introduction to sociology: culture and society in transition. The Yale Cultural Sociology Series, Paradigm Publishers, Boulder, CO, USA. Ananda J, Herath G (2003). The use of analytic hierarchy process to incorporate stakeholder preferences into regional forest planning. Forest Policy and Economics 5: 13-26. - doi: 10.1016/ S1389-9341(02)00043-6

Ananda J, Herath G (2005). Evaluating public risk preferences in forest land-use choices using multi-attribute utility theory. Ecological Economics 55: 408-419. - doi: 10.1016/j.ecolecon.2004.12. 015

Ananda J, Herath G (2008). Multi-attribute preference modelling and regional land-use planning. Ecological Economics 65: 325-335. - doi: 10.10 16/j.ecolecon.2007.06.024

Ananda J, Herath G (2009). A critical review of multi-criteria decision making methods with special reference to forest management and planning. Ecological Economics 68: 2535-2548. doi: 10.1016/j.ecolecon.2009.05.010

Anderson C, Bezley K, Boxall J (2009). Lessons for PPGIS from the application of a decisionsupport tool in the Nova Forest Alliance of Nova Scotia, Canada. Journal of Environmental Management 90: 2081-2089. - doi: 10.1016/j.jenvman.2007.08.031

Arnstein SR (1969). A ladder of citizen participation. Journal of American Institute of Planners 35: 216-224. - doi: 10.1080/01944366908977 225

Arrow KJ, Sen AK, Suzumura K (2002). Handbook of social choice and welfare (vol. 1). Elsevier, Amsterdam, The Netherlands.

Atmis E, Özden S, Lise W (2007). Public participation in forestry in Turkey. Ecological Economics 62: 352-359. - doi: 10.1016/j.ecolecon. 20 06.07.002

Beierle TC, Cayford J (2002). Democracy in practice: public participation in environmental decisions. Resources for the future, Washington, DC, USA.

Belton S, Stewart TS (2002). Multiple criteria decision analysis. An integrated approach. Kluwer Academic Publishers, Massachusetts, USA.

Berninger K, Kneeshaw D, Messier C (2009). Effects of presenting forest simulation results on the forest values and attitudes of forestry professionals and other forest users in Central Labrador. Forest Policy and Economics 11: 126-133. doi: 10.1016/j.forpol.2008.11.002

Beverly J, Uto K, Wilkes J, Bothwell P (2008). Assessing spatial attributes of forest landscape values: An internet-based participatory mapping approach. Canadian Journal of Forest Research 38: 289-303. - doi: 10.1139/X07-149

Booth A, Halseth G (2011). Why the public thinks natural resources public participation processes fail: a case study of British Columbia communities. Land Use Policy 28: 898-906. - doi: 10.10 16/j.landusepol.2011.03.005

Brody SD, Cash SB (2004). Why resource-based industries should participate in collaborative ecosystem approaches to management: a concep- 
tual framework. Hazard Reduction and Recovery Center. Technical Report No. 04-01R, Texas A\&M University, College Station, TX, USA. Brody SD, Cash SB, Dyke J, Thornton S (2006). Motivations for the forestry industry to participate in collaborative ecosystem management initiatives. Forest Policy and Economics 8: 123 134. - doi: 10.1016/j.forpol.2004.06.002

Brown G, Reed P (2009). Public Participation GIS: a new method for national forest planning. Forest Science 55: 166-182.

Brown G, Weber X (2011). Public Participation GIS: a new method for national park planning. Landscape and Urban Planning 102: 1-15. - doi: 10.1016/j.landurbplan.2011.03.003

Buchy M, Hoverman S (2000). Understanding public participation in forest planning: a review. Forest Policy and Economics 1: 15-25. - doi: 10.1016/S1389-9341(00)00006-X

Cantiani MG (2012). Forest planning and public participation: a possible methodological approach. iForest 5: 72-82. - doi: 10.3832/ifor06 02-009

Conrad E, Cassar LF, Christie M, Fazey I (2011). Hearing but not listening? A participatory assessment of public participation in planning. Environment and Planning C: Government and Policy 29: 761-782 - doi: 10.1068/c10137

Côté M, Bouthillier L (2002). Assessing the effect of public involvement processes in forest management in Quebec. Forest Policy and Economics 4: 213-225. - doi: 10.1016/S1389-9341(02)0000 2-3

Collier MJ, Scott M (2009). Conflicting rationalities, knowledge and values in scarred landscapes. Journal of Rural Studies 25: 267-277. - doi: 10.1016/j.jrurstud.2008.12.002

Cost Action FP0804 (2010). Forests Management Decisión Support Systems (FORSYS). [online] URL: http://fp0804.emu.ee/wiki/index.php/Participatory_processes

Clement JM, Cheng AS (2010). Using analyses of public value orientations, attitudes and preferences to inform national forest planning in $\mathrm{Co}$ lorado and Wyoming. Applied Geography 31: 393-400. - doi: 10.1016/j.apgeog.2010.10.001

Díaz L, Granell C, Huerta J, Gould M (2012).

Web 2.0 broker: a standards-based service for spatio-temporal search of crowd-sourced information. Applied Geography 35: 448-459. - doi: 10.1016/j.apgeog.2012.09.008

Díaz-Balteiro L, Romero C (2008). Making forestry decisions with multiple criteria: a review and an assessment. Forest Ecology and Management 255: 3222-3241. - doi: 10.1016/j.foreco. 2008.01.038

Díaz-Balteiro L, Gonzalez-Pachón J, Romero C (2009). Forest management with multiple criteria and multiple stakeholders: An application to two public forests in Spain. Scandinavian Journal of Forest Research 24: 87-93. - doi: 10.1080/02827 580802687440

Domínguez G, Carbonell X, Plana E, Pecurul M, Rodríguez I (2005). Participación pública en el Plan General de Política Forestal en Cataluña [Public participation in the Forest Policy General
Plan of Catalonia]. In: Proceedings of the "IV Congreso Forestal Español". Zaragoza (Spain) 26-30 Sep 2005, pp. 7. [in Spanish]

Domínguez Torres G (2008). A wish, a fear and a complaint: understanding the (dis)engagement of forest owners in forest management. European Journal of Forest Research 130: 435-450. - doi: 10.1007/s10342-009-0332-0

Domínguez G, Shannon M (2009). Understanding forest owners in a Mediterranean context. Constructing theory through descriptive and interpretational analysis. A study case in Catalonia. Msc Thesis, University of Freiburg, Germany.

Dovie DBK (2003). Whose involvement? Can hierarchical valuation scheme intercede for participatory methods for evaluating secondary forest resource use? Forest Policy and Economics 5: 265-283. - doi: 10.1016/S1389-9341(02)000667

Düzgün M (2003). Advancement of forest village communities through effective participation and partnership in state-owned forestry administration: Turkey's case. In: Proceedings of the "XII" World Forestry Congress". Québec City (Canada) 21-28 Sep 2003. [online] URL: http://www.fao.org/DOCREP/ARTICLE/WFC/XII/0223C1.HTM

Elcome D, Baines J (1999). Steps to success. Working with residents and neighbours to develop and implement plans for protected areas. IUCN, Commission on Education and Communication, European Committee for EE, Gland, Switzerland, pp. 42.

Elsasser P (2002). Rules for participation and negotiation and their possible influence on the content of a national forest program. Forest Policy and Economics 4: 291-300. - doi: 10.1016/S13 89-9341(02)00071-0

Faehnle M, Tyrväinen L (2013). A framework for evaluating and designing collaborative planning. Land Use Policy 34: 332-341 - doi: 10.1016/j. landusepol.2013.04.006

Garmendia E, Stagl S (2010). Public participation for sustainability and social learning: concepts and lessons from three case studies in Europe. Ecological Economics 69: 1712-1722. - doi: 10.1016/j.ecolecon.2010.03.027

Germain RH, Floyd DW, Stehman SV (2001). Public perceptions of the USDA Forest Service public participation process. Forest Policy and Economics 3: 113-124. - doi: 10.1016/S1389-93 41(01)00065-X

Gómez-Vázquez I, Álvarez-Álvarez P, MareyPérez MF (2009). Conflicts as enhancers or barriers to the management of privately owned common land: a method to analyze the role of conflicts on a regional basis. Forest Policy and Economics 11: 617-627. - doi: 10.1016/j.forpol.20 09.09.001

Glück P (1999). National Forest Programmes significance of a forest policy framework. In: "Formulation and Implementation of National Forest Programmes" (Glueck P, OEsten G, Schanz H, Colz K-R eds). European Forest Institute Proceedings, Joensuu, Finland, pp. 39-51.

Hajkowicz SA, Young M, Wheeler S, MacDonald
DH, Young D (2000a). Supporting decisions: understanding natural resource management assessment techniques. A Report to the Land and Water Resources Research and Development Corporation, CSIRO, Canberra, Australia, pp. 136. [online] URL: http://www.researchgate.net/ publication/4763707 Supporting Decisions Un derstanding_natural_resource_management_assessment_techniques/file/72e7e5228ea72e5e62.p df

Hajkowicz, SA, Wheeler S, Young D (2000b). An evaluation of options for the Lower Murray reclaimed irrigation areas using multiple criteria analysis. In: Proceedings of the "Australian Agricultural and Resource Economics Society Conference". Canberra (Australia) 12-15 Feb 2002, pp. 13. [online] URL: http://ageconsearch.umn. edu/bitstream/125098/2/Hajkowic.pdf

Hansmann R, Koellner T, Scholz RW (2006). Influence of consumers' socioecological and economic orientations on preferences for wood products with sustainability labels. Policy and Economics 8: 239-250. - doi: 10.1016/j.forpol. 2004.06.005

Hellström E (2001). Conflict cultures - qualitative comparative analysis of environmental conflicts in forestry. Silva Fennica Monographs 2, pp. 109

Hiedanpää J (2005). The edges of conflict and consensus: a case for creativity in regional forest policy in southwest Finland. Ecological Economics 55: 485- 498. - doi: 10.1016/j.ecolecon. 2004.12.007

Higgs G, Berry R, Kidner D, Langford M (2008). Using IT approaches to promote public participation in renewable energy planning: prospects and challenges. Land Use Policy 25: 596-607. doi: 10.1016/j.landusepol.2007.12.001

Hiltunen V, Kangas J, Pykäläinen J (2008). Voting methods in strategic forest planning experiences from Metsähallitus. Forest Policy and Economics 10: 117-127. - doi: 10.1016/j.for pol.2007.06.002

Hiltunen V, Kurttila M, Leskinen P, Pasanen K, Pykäläinen J (2009). Mesta: an internet-based decision-support application for participatory strategic-level natural resources planning. Forest Policy and Economics 11: 1-9. - doi: 10.1016/j.forpol.2008.07.004

Hjortsø CN (2004). Enhancing public participation in natural resource management using Soft OR - an application of strategic option development and analysis in tactical forest planning. European Journal of Operational Research 152: 667-683. - doi: 10.1016/S0377-2217(03)000651

ILO (2000). Public participation in forestry in Europe and North America: Report of the team of specialists on participation in forestry. Report WP 163, FAO/ECE/ILO Joint Committee Team, International Labour Office, Geneva, Switzerland.

Janse G (2008). Communication between forest scientists and forest policy-makers in Europe - a survey on both sides of the science/policy interface. Forest Policy and Economics 10: 183-194. 
- doi: 10.1016/j.forpol.2007.10.001

Janse G, Konijnendijk C (2007). Communication between science, policy and citizens in public participation in urban forestry - experiences from the Neighbourwoods project. Urban Forestry and Urban Greening 6: 23-40. - doi: 10.1016/j.ufug. 2006.09.005

Kangas J (1994). An approach to public participation in strategic forest management planning. Forest Ecology and Management 70: 75-88. doi: 10.1016/0378-1127(94)90076-0

Kangas J, Store R (2003). Internet and teledemocracy in participatory planning of natural resources management. Landscape and Urban Planning 62: 89-101. - doi: 10.1016/S0169-2046(02)001 25-1

Kangas J, Kangas A (2005). Multiple criteria decision support in forest management - the approach, methods applied, and experiences gained. Forest Ecology and Management 207 133-143. - doi: 10.1016/j.foreco.2004.10.023

Kangas J, Store R, Kangas R (2005). Socioecological landscape planning approach and multicriteria acceptability analysis in multiple-purpose forest management. Forest Policy and Economics 7: 603-614. - doi: 10.1016/j.forpol.2003.12.001

Kangas A, Laukkanen S, Kangas J (2006). Social choice theory and its applications in sustainable forest management - a review. Forest Policy and Economics 9: 77-92. - doi: 10.1016/j.forpol. 2005.02.004

Kangas A, Saarinen N, Saarikoski H, Leskinen LA, Hujala T, Tikkanen J (2010). Stakeholder perspectives about proper participation for Regional Forest Programmes in Finland. Forest Policy and Economics 12: 213-222. - doi: 10.1016/j.forpol.2009.10.006

Kant S, Lee S (2004). A social choice approach to sustainable forest management: an analysis of multiple forest values in northwestern Ontario. Forest Policy and Economics 6: 215- 227. - doi: 10.1016/j.forpol.2004.03.005

Kouplevatskaya-Yunusova I, Buttoud G (2006) Assessment of an iterative process: The double spiral of re-designing participation. Forest Policy and Economics 8: 529-541. - doi: 10.1016/j.forpol.2005.07.010

Kurttila M, Pesonen M, Kangas J, Kajanus M (2000). Utilizing the analytic hierarchy process (AHP) in SWOT analysis - a hybrid method and its application to a forest-certification case Forest Policy and Economics 1: 41-52. - doi: 10.1016/S1389-9341(99)00004-0

Laukkanen S, Palander T, Kangas J, Kangas A (2005). Evaluation of the multicriteria approval method for timber-harvesting group decision support. Silva Fennica 39: 249-264.

Leskinen LA (2004). Purposes and challenges of public participation in regional and local forestry in Finland. Forest Policy and Economics 6: 605618. - doi: 10.1016/S1389-9341(03)00009-1

Leskinen P, Kangas J (2005). Multi-criteria natural resource management with preferentially dependent decision criteria. Journal of Environmental Management 77: 244-251. - doi: 10.10 16/j.jenvman.2005.03.008
Lexer MJ, Vacik H, Palmetzhofer D, Oitzinger G (2005). A decision support tool to improve forestry extension services for small private landowners in southern Austria. Computers and Electronics in Agriculture 49: 81-102. - doi: 10.1016/j.compag.2005.02.004

Marey-Pérez MF, Rodríguez-Vicente V, CrecenteMaseda R (2006). Using GIS to measure changes in temporal and spatial dynamics of forestland: experiences from north-west Spain. Forestry 79: 409-423. - doi: 10.1093/forestry/cpl027

Marey-Pérez MF, Rodríguez-Vicente V (2009). Forest transition in northern Spain: local responses on large-scale programmes of field afforestation. Land Use Policy 26: 139-156. - doi: 10.10 16/j.landusepol.2008.02.004

Martin A (2003). On knowing what trees to plant: local and expert perspectives in the Western Ghats of Karnataka. Geoforum 34: 57-69. - doi: 10.1016/S0016-7185(02)00075-1

Martin WE, Shields DJ, Tolwinski B, Kent B (1996). An application of social choice theory to U.S.D.A. Forest Service decision making. Journal of Policy Modeling 18 (6): 603-621. - doi: 10.1016/S0161-8938(95)00132-8

Martins H, Borges JG (2007). Addressing collaborative planning methods and tools in forest management. Forest Ecology Management 248: 107-118. - doi: 10.1016/j.foreco.2007.02.039

Mau-Crimmins T, Steigure JE, Dennis D (2005). AHP as a means for improving public participation: a pre-post experiment with university students. Forest Policy and Economics 7: 501-514. doi: 10.1016/j.forpol.2003.08.001

McCool SF, Guthrie K (2001). Mapping the dimensions of successful public participation in messy natural resources management situations. Society and Natural Resources 14: 309- 323. doi: 10.1080/713847694

McDaniels TL, Roessler C (1998). Multiattribute elicitation of wilderness preservation benefits: a constructive approach. Ecological Economics 27: 299-312. - doi: 10.1016/S0921-8009(98)00 005-6

Meitner MJ, Sheppard SRJ, Cavens D, Gandy R, Picard P, Harshaw H, Harrison D (2005). The multiple roles of environmental data visualization in evaluating alternative forest management strategies. Computers and Electronics in Agriculture 49: 192-205. - doi: 10.1016/j.compag.2005. 03.002

Mendoza GA, Prabhu R (2002). Enhancing participatory planning of community-managed forest using problem structuring models and approaches: experiences from a case study. Working Paper GAM-2003-1, Department of Natural Resources and Environmental Sciences, University of Illinois, Champaign, IL, USA.

Mendoza GA, Prabhu R (2003). Qualitative multicriteria approaches to assessing indicators of sustainable forest resource management. Forest Ecology and Management 174: 329-343. - doi: 10.1016/S0378-1127(02)00044-0

Mendoza GA, Prabhu R (2005). Combining participatory modeling and multi-criteria analysis for community-based forest management. Forest
Ecology and Management 207: 145-156. - doi: 10.1016/j.foreco.2004.10.024

Mendoza GA, Prabhu R (2006). Participatory modeling and analysis for sustainable forest management: overview of soft system dynamics models and applications. Forest Policy and Economics 9: 179-196. - doi: 10.1016/j.forpol.2005. 06.006

Mendoza GA, Martins H (2006). Multi-criteria decision analysis in natural resource management: a critical review of methods and new modelling paradigms. Forest Ecology and Management 230: 1-22. - doi: 10.1016/j.foreco.2006. 03.023

Mose I, Weixlbauner N (2007). A new paradigm for protected areas in Europe? In: "Protected areas and regional development in Europe: towards a new model for the $21^{\text {st }}$ century" (Mose I, Weixelbumer $\mathrm{N}$ eds). Ashgate, Aldershot, UK, pp. 3-20.

Niemelä, J, Young J, Alard D, Askasibar M, Henle K, Johnson R, Kurttila M, Larsson T, Matouch $\mathrm{S}$, Nowicki P, Paiva R, Portoghesi L, Smulders R, Stevenson A, Tartes U, Watt A (2005). Identifying, managing and monitoring conflicts between forest biodiversity conservation and other human interests in Europe Forest. Policy and Economics 7: 877- 890. - doi: 10.1016/j.for pol.2004.04.005

Ojha HR, Cameron J, Kumar C (2009). Deliberation or symbolic violence? The governance of community forestry in Nepal. Forest Policy and Economics 11: 365-374. - doi: 10.1016/j.forpol. 2008.11.003

Panagopoulos T (2009). Linking forestry, sustainability and aesthetics. Ecological Economics 68: 2485-2489. - doi: 10.1016/j.ecolecon.2009. 05.006

Penker M (2009). Landscape governance for or by the local population? A property rights analysis in Austria. Land Use Policy 26: 947-953. - doi: 10.1016/j.landusepol.2008.11.007

Pocewicz A, Schnitzer R, Nielsen-Pincus M (2010). The social geography of southern Wyoming: Important places, development, and natural resource management, The Nature Conservancy, Lander, WY, USA, pp. 16. [online] URL: http://www.nature.org/wherewework/northamerica/states/wyoming/files/sciencemappingsocialvalues2010.pdf

Pretty JN (1994). Alternative systems of inquiry for sustainable agriculture. IDS Bulletin 25 (2): 37-48. - doi: 10.1111/j.1759-5436.1994.mp2500 2004.x

Pretty J, Scoones IC, Guijt I, Thompson J (1995). A trainers guide for participatory learning and action. IIED, London, UK.

Primmer E, Kyllönen S (2006). Goals for public participation implied by sustainable development, and the preparatory process of the Finnish National Forest Programme. Forest Policy and Economics 8: 838-853. - doi: 10.1016/j.forpol. 2005.01.002

Purnomo H, Mendoza G, Prabhu R (2004). Model of collaborative planning of community-managed resources based on qualitative soft systems 
approach. Journal of Tropical Forest Science 16: 106-131.

Richard T, Burns S (1998). Beyond "scoping". Citizens and San Juan National forest managers, learning together. Journal of Forestry: 39-43. [online] URL: http://www.r5.fs.fed.us/emc/nfma/ collaborative_processes/Beyond_Scoping.pdf

Saarikoski H, Tikkanen J, Leskinen LA (2010). Public participation in practice: assessing public participation in the preparation of regional forest programs in northern Finland. Forest Policy and Economics 12: 349-356. - doi: 10.1016/j.forpol. 2010.02.006

Saaty TL (1977). A scaling method for priorities in hierarchical structures. Journal of Mathematical Psychology 15: 234-281. - doi: 10.1016/ 0022-2496(77)90033-5

Saaty TL (1980). The analytic hierarchy process. McGraw-Hill, New York, USA, pp. 287.

Scardina AV, Mortimer MJ, Dudley L (2007). Getting past the who and how many to the how and why in USDA Forest Service public involvement processes. Forest Policy and Economics 9: 883-902. - doi: 10.1016/j.forpol.2006.07.003

Schmoldt DL, Peterson DL (2000). Analytical group decision making in natural resources: methodology and application. Forest Science 46: 62-75.

Seely B, Nelson J, Wells R, Peter B, Meitner M, Anderson A, Harshaw H, Sheppard S, Bunnell FL, Kimmins H, Harrison D (2004). The application of a hierarchical, decision-support system to evaluate multi-objective forest management strategies: a case study in northeastern British Columbia, Canada. Forest Ecology and Management 199: 283-305. - doi: 10.1016/j.foreco. 2004.05.048

Selman P (2004). Community participation in the planning and management of cultural landscapes. Journal of Environmental Planning and Management 47: 365-395. - doi: 10.1080/09640 56042000216519

Sewell WRD, O'Riordan T (1976). Natural resources for a democratic society: public participation in decision-making. Westview Press, Boulder, CO, USA.

Shannon M (1999). Moving from the limits and problems of rational planning toward a collaborative and participatory planning approach. In: "Formulation and Implementation of National
Forest Programmes" (Glück P, Oesten G, Schanz H, Colz K-R eds). European Forest Institute Proceedings, Joensuu, Finland, pp. 139-151.

Sheppard SRJ, Meitner M (2005). Using multi-criteria analysis and visualisation for sustainable forest management planning with stakeholder groups. Forest Ecology and Management 207: 171-187. - doi: 10.1016/j.foreco.2004.10.032

Shindler B, Neburka J (1997). Public participation in forest planning. Journal of Forestry 17-19. Shindler BA, Brunson M, Stankey GH (2002). Social acceptability of forest conditions and management practices: a problem analysis. General Technical Report PNW-GTR-537, Pacific Northwest Research Station, USDA Forest Service, Portland, OR, USA, pp. 73. [online] URL: http://www.fs.fed.us/pnw/pubs/pnw_gtr537.pdf

Silvennionen H, Alho J, Kolehmainen O (2001). Prediction models of landscape preferences at the forest stand level. Landscape Urban Planning 56: 11-20. - doi: 10.1016/S0169-2046(01)001 63-3

Sipilä M, Tyrväinen L (2005). Evaluation of collaborative urban forest planning in Helsinki, Finland. Urban Forestry and Urban Greening 4: 112. - doi: 10.1016/j.ufug.2005.06.002

Stenseke M (2009). Local participation in cultural landscape maintenance: lessons from Sweden. Land Use Policy 26: 214-223. - doi: 10.1016/j. landusepol.2008.01.005

Stewart JMP, Sinclair AJ (2007). Meaningful public participation in environmental assessment: perspectives from Canadian participants, proponents and government. Journal of Environmental Assessment Policy and Management 9 (2): 161-183. - doi: 10.1142/S1464333207002 743

Suárez de Vivero J, Rodríguez Mateos JC, Florido del Corral D (2008). The paradox of public participation in fisheries governance. The rising number of actors and the devolution process. Marine Policy 32: 319-325. - doi: 10.1016/j.marpol. 2007.06.005

Sugimura K, Howard TE (2008). Incorporating social factors to improve the Japanese forest zoning process. Forest Policy and Economics 10: 161-173. - doi: 10.1016/j.forpol.2007.08.005

Swedeen P (2006). Post-normal science in practice: a Q study of the potential for sustainable forestry in Washington State, USA. Ecological
Economics 57: 190-208. - doi: 10.1016/j.ecolecon.2005.04.003

Tikkanen J, Isokääntä T, Pykäläinen, Leskinen P (2006). Applying cognitive mapping approach to explore the objective-structure of forest owners in a northern Finnish case area. Forest Policy and Economics 9: 139-152. - doi: 10.1016/j.forpol 2005.04.001

Tourain A (1969). La societé post-industrialle. Bibliothèque Médiations 61, Denoël, Paris, France.

Tuler S, Webler T (1999). Voices from the forest: what participants expect of a public participation process. Society and Natural Resources 12: 437 453. - doi: 10.1080/089419299279524

Tyrväinen L, Gustavsson R, Konijnendijk C, Ode A (2006). Visualization and landscape laboratories in planning, design and management of urban woodlands. Forest Policy and Economics 8: 811- 823. - doi: 10.1016/j.forpol.2004.12.005

Twery MJ, Hornbeck JW (2001). Incorporating water goals into forest management decisions at a local level. Forest Ecology and Management 143: 87-93. - doi: 10.1016/S0378-1127(00)005 08-9

Vacik H, Lexer MJ (2001). Application of a spatial decision support system in managing the protection forests of Vienna for sustained yield of water resources. Forest Ecology and Management 143: 65-76. - doi: 10.1016/S0378-1127(00) 00506-5

Vainikainen N, Kangas A, Kangas J (2008). Empirical study on voting power in participatory forest planning. Journal of Environmental Management 88: 173-180. - doi: 10.1016/j.jenvman. 2007.02.004

Weber N, Christophersen T (2002). The influence of nongovernmental organizations on the creation of Natura 2000 during the European Policy process. Forest Policy and Economics 4: 1-12. doi: 10.1016/S1389-9341(01)00070-3

Webler T, Kastenholz H, Renn O (1995). Public participation in impact assessment: a social learning perspective. Environmental Impact Assessment Review 15: 443-463. - doi: 10.1016/01959255(95)00043-E

World Commission on Environment and Development (1987). Our common future. Oxford University Press, Oxford, UK, pp. 416. 